\title{
OPEN
}

\section{Publisher Correction: Impact of alloy fluctuations and Coulomb effects on the electronic and optical properties of c-plane GaN/AIGaN quantum wells}

\author{
A. A. Roble, S. K. Patra, F. Massabuau, M. Frentrup, M. A. Leontiadou, P. Dawson, \\ M. J. Kappers, R. A. Oliver, D. M. Graham \& S. Schulz
}

Correction to: Scientific Reports https://doi.org/10.1038/s41598-019-53693-2, published online 11 December 2019

This Article contains a typographical error in the Results and Discussion section under subheading 'Experimental analysis of the optical properties' where,

“ $\{\mathrm{L}\} \_\{\mathrm{w}\}=2.4 \mathrm{~nm} "$

should read:

"L $\mathrm{L}_{\mathrm{w}}=2.4 \mathrm{~nm} "$

(c) (i) Open Access This article is licensed under a Creative Commons Attribution 4.0 International cc) License, which permits use, sharing, adaptation, distribution and reproduction in any medium or format, as long as you give appropriate credit to the original author(s) and the source, provide a link to the Creative Commons license, and indicate if changes were made. The images or other third party material in this article are included in the article's Creative Commons license, unless indicated otherwise in a credit line to the material. If material is not included in the article's Creative Commons license and your intended use is not permitted by statutory regulation or exceeds the permitted use, you will need to obtain permission directly from the copyright holder. To view a copy of this license, visit http://creativecommons.org/licenses/by/4.0/.

(c) The Author(s) 2020 